Crrizens of the United States are entitled under their constitution to bear arms, and they believe in using them. In addition to shooting public figures and wild game, they are also accustomed to collect any rarities they encounter "for scientific purposes". There is a conspiracy of silence over this in North America, where for example the senior ornithological journal has refused to publish any comments on reports that specimens of the first Little Gulls Larus minutus and Wood Sandpipers Tringa glareola found nesting in North America were promptly collected despite the fact that they are easily recognised and that there was already ample material available. Even the supposedly militant Audubon Societies have said nothing about the situation. There has, however, been a growing chorus of complaint where the same policies have been followed abroad. Many of the atrocities have been perpetrated by young and inexperienced people, brought up in an unhealthy tradition by their seniors who tend to escape the blame, so it is worthy of note that one Daniel has at least been brought to judgement in his own courts.

For several months now there has been an excited twittering in international ornithological circles as the news went round that Professor Charles Sibley, formerly of Cornell University and now of Yale University, who was awarded the American Ornothologists' Union's Brewster Memorial Award for the electrophoretic analysis of egg-white proteins in 1971 and subsequently found participating in the international to the limit to enable Professor Sibley British Home Office Advisory Commit-

Egg collector collected

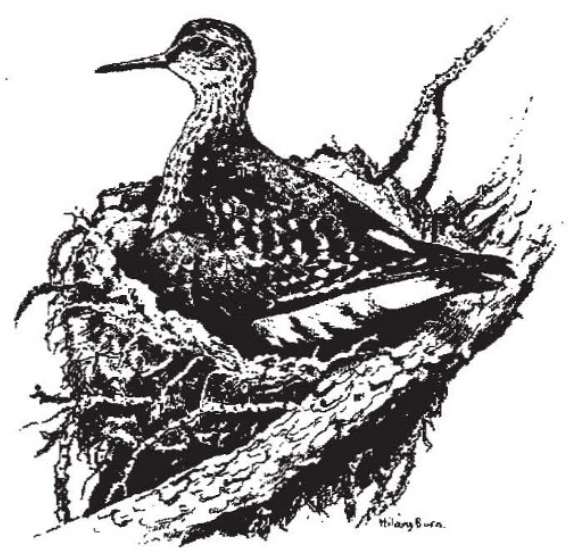

Wood Sandpiper: collected

egg trade. It seems that by a skilful piece of deduction Richard Porter of the British Royal Society for the Protection of Birds, concluded that a local egg collector must be dealing with foreign parts, located allegedly incriminating correspondence with Professor Sibley and referred it to the American authorities. Professor Sibley's files at Yale were then inspected, with the result that on May 20 he was fined $\$ 3,000$ under the Lacey Act for six cases of "illegally importing bird parts taken abroad in violation of foreign wild life laws", five of them in Britain.

The situation is made worse by the fact that for at least fifteen years the to obtain material legally, and many British ornithologists had been assisting him with this. He justified his decision to exceed his allocation by telling the British Sunday Times (June 16) that it was an insult to his scientific standing imposed by emotional bird conservation groups with little knowledge of bird population dynamics, which he felt entitled to ignore because "the idea that taking a few eggs could endanger a species is the most ridiculous thing you could imagine . . I I say 'fine, we'll pay the penalty, but you are going to have to listen to the real experts, because you are not the real experts'"

The British Home Office Advisory Committees consist of people of a most unemotional sort who are internationally recognised to have made more important contributions to the study of population dyanmics than Professor Sibley. They must have been watching the amount of material that he had already received through legal means, which is known to have been large, rather carefully, and it would be interesting to know where Professor Sibley expects to find greater "experts". It is surprising to find a person in such a responsible position at such a distinguished institution first behaving in such a way and then indulging in such an outburst when he was found out. If senior people behave like this, it is hardly surprising that the conduct of some junior American ornithologists is not all it should be. It is good to see the American authorities take the first steps towards putting their house in order. But there is still bigger game in the woods.-From W. R. P. Bourne.
THE British government has accepted in principle the main recommendations contained in the report of a committee which enquired into causes of the London smallpox outbreak of 1973, when two people died and widespread disruption was caused as vaccination was demanded for four to five millions.

The circumstances leading to the appointment of a committee of enquiry were that a graduate laboratory technician employed at the London School of Hygiene and Tropical Medicine was admitted to hospital on March 16th suffering from suspected meningitis or glandular fever. In fact she had contracted smallpox, and after being placed in an open ward at St. Mary's Hospital, Harrow Road, she came into contact not only with other patients but with two visitors who subsequently contracted the disease and died.

There was serious disquiet that a laboratory worker could have become infected while working in the laboratory; that having become infected, she

\section{Smallpox report}

could spend a week in the general ward while the disease remained undiagnosed; and further, that even after a provisional diagnosis of smallpox, another twelve days elapsed before the visitors were traced, by which time it was too late to save their lives.

The committee found, among other things, that inadequate safety measures were in force at the London School of Hygiene and Tropical Medicine, where the technician was infected while watching the harvesting of pox virus. The pox virus laboratory was said to be old fashioned, poorly decorated, overcrowded and dirty - conditions which, said the report, led to a lowering of safety standards.

Lethal smallpox virus samples were stored in a corridor in an unlocked deep-freeze, workers from other laboratories passed to and fro, using equipment housed in the pox virus lab, and there was an inadequate immunisation policy in the School's Department of Microbiology. Each unit within the department was left to make its own arrangements in relation to its own hazards.

The report recommended the establishment of a permanent committee to draw up and enforce a code of practice for work on pathogens constituting a major threat to public health; the appointment of a safety officer at the School (already implemented); and, since many of the shortcomings resulted from cash shortages in the first place, financial aid to implement the safety proposals.

Failure to trace contacts in the case were caused by a catalogue of administrative errors, coupled with the fact that no one realised the urgency of the situation, says the report, recommending the appointment of regional specialists to supervise control of outbreaks, consideration of compulsory isolation of contracts, and better diagnostic guides for doctors. 